\title{
Evaluation of sequential application of insecticides against pigeonpea pod fly Melanagromyza obtusa (Mall)
}

\author{
S. D. Bantewad*, R. A. Chavan and J. E. Jahagirdar
}

Agricultural Research Station, Badnapur, Jalna (M.S.) India

\section{ARITCLE INFO}

Received : 18.09 .2017

Revised : 03.03.2018

Accepted : 11.03 .2018

\section{KEY WORDS :}

Insecticides, Melanagromyza obtusa, Pigeonpea, Pod fly
*Corresponding author:

sdbantewad@ rediffmail.com

\begin{abstract}
The present investigation was conducted during Kharif 2016-17 on field of Department of Agricultural Entomology, Agril. Research Station Badnapur. The experiment was planned in Randomized Block Design with cultivar BSMR 736 and gross plot size 7.20 $\mathrm{x} 4.50 \mathrm{~m}^{2}$ with eight treatments replicated thrice with the object to study the sequential application of insecticides against against pigeonpea pod fly, Melanagromyza obtuse. All the insecticides were found to be significantly superior in recording minimum population of pod fly over untreated control. Among different insecticides, chlorantraniliprole followed by flubendiamide and Dimethoate recorded the least population of pod fly at 3,7 and 14 days after spray and which was statistically at par with the sequential application of insecticides as chlorantraniliprole followed by indoxacarb and acetamiprid in respect of reducing the population, pod damage of pod fly and higher grain yield. These findings indicate that the pigeonpea crop required two sprays of insecticides from pod initiation stage at 20 days interval for the management of pigeonpea pod fly, Melanagromyza obtusa.
\end{abstract}

How to view point the article : Bantewad, S.D., Chavan, R.A. and Jahagirdar, J.E. (2018). Evaluation of sequential application of insecticides against pigeonpea pod fly Melanagromyza obtusa (Mall). Internat. J. Plant Protec., 11(1) : 18-22, DOI : 10.15740/HAS/IJPP/11.1/18-22. 